\title{
POLITYKA HISTORYCZNA I JEJ GRANICE
}

Francuski historyk Pierre Nora zauważył, że ponowoczesność niesie ze sobą daleko idące przemiany stosunku ludzi do przeszłości. Stopniowo traci na znaczeniu kanon symboliczny państwa narodowego, a w zamian pojawia się wiele niepowiązanych ze sobą, ,języków upamiętniania”. Ma to świadczyć o pojawieniu się nowego typu relacji z przeszłością: dobrowolnej, żywej, nieustrukturalizowanej i podlegającej nieustannym przekształceniom ${ }^{1}$. Pojawia się wobec tego pytanie, czy państwo dysponuje jakimikolwiek środkami umożliwiającymi zahamowanie niepokojącej tendencji i przywrócenie dawnego sposobu myślenia o pamięci i tożsamości. Również w Polsce nastąpiło w ostatnich latach gwałtowne ożywienie debaty na temat roli państwa w kształtowaniu stosunku obywateli do historii i dziedzictwa narodowego, co w oczywisty sposób związane było $\mathrm{z}$ pojawieniem się $\mathrm{w}$ retoryce partii konserwatywnych hasła polityki historycznej. Apogeum owej debaty przypada na lata 2005-2007, kiedy to ukazał się szereg publikacji książkowych oraz numerów tematycznych czasopism społeczno-politycznych, popularnonaukowych i naukowych poświęconych zagadnieniom polityki historycznej i pamięci. Po tym okresie, gdy tematyka straciła nieco ze swojej rangi i powraca na powierzchnię dyskursu publicznego sporadycznie, w miarę wyłaniania się kolejnych zagadnień spornych, pojawiły się głosy, by poddać problem stosownemu namysłowi teoretycznemu historii i nauk społecznych. Stoi za nimi uzasadniona chęć przekonania się, czy kategoria, która tak dobrze sprawdziła się jako instrument marketingu politycznego, ma również godne odnotowania znaczenie teoretyczne. Obszerną analizę zjawiska z perspektywy socjologicznej przeprowadził Lech M. Nijakowski ${ }^{2}$.

Niniejszy artykuł będzie dotyczył granic polityki historycznej w dwojakim sensie. Po pierwsze, mowa będzie o granicach, które praktykom tego rodzaju stara się wyznaczyć część środowiska profesjonalnych historyków. Po drugie, będzie mowa o ograniczeniach teoretycznych dominującego w Polsce sposobu pojmowania polityki historycznej. Pierwsza część wywodu będzie próba zwięzłego podsumowania stanu polskiej debaty na temat polityki historycznej. W drugiej części, stopniowo wprowadzając elementy perspektywy badawczej właściwej socjologii wiedzy oraz dyscyplin pokrewnych (socjologii pamięci

\footnotetext{
${ }^{1}$ P. Nora, The Era of Commemoration, w: L. D. Kritzman (red.), Realms of Memory: The Construction of the French Past, t. 3: Symbols, Columbia University Press, New York 1998, s. 614-615.

${ }^{2}$ L. M. Nijakowski, Polska polityka pamięci. Esej socjologiczny, Wydawnictwa Akademickie i Profesjonalne, Warszawa 2008.
} 
zbiorowej, socjologii nauki), scharakteryzuję szczególnie istotny nurt krytyki tego zjawiska formułujący się na polu naukowej historii; w trzeciej i czwartej poczynię kilka uwag na temat tego, jakim dyskursem jest polityka historyczna, i przedstawię sposób konceptualizacji tego zagadnienia alternatywny wobec dominującego w polskiej debacie.

\section{POLITYKA HISTORYCZNA JAKO TEMAT DEBATY PUBLICZNEJ}

Pojęcie polityki historycznej pojawiło się w polskiej debacie publicznej $\mathrm{w}$ związku z trzema okolicznościami. Mam tu na myśli spór o masakrę w Jedwabnem i książkę Sasiedzi autorstwa Jana Tomasza Grossa, problem budowy Centrum przeciw Wypędzeniom i ewentualnych roszczeń obywateli niemieckich wobec majątków utraconych po II wojnie światowej oraz zmianę władzy w Polsce $\mathrm{w}$ związku $\mathrm{z}$ wyborami parlamentarnymi i prezydenckimi w 2005 r., wygranymi przez zwolenników sformułowania tak zwanej nowej polityki historycznej. Nie oznacza to, że dyskurs polityki historycznej został w efekcie tych zdarzeń powołany do życia z niczego -istniał on wcześniej, jednak w postaci rozproszonej i mniej spektakularnej, z dala od centrum uwagi opinii publicznej.

Obowiązujące rozumienie kategorii ,,polityka historyczna” zostało ukształtowane przez praktykę polityczną i marketing polityczny, natomiast podjęcie tej tematyki w refleksji naukowej czy quasi-naukowej miało w dużej mierze charakter wtórny, dlatego też nie istnieją zasadnicze rozbieżności w definiowaniu polityki historycznej czy polityki pamięci. Choć poszczególni autorzy mają różne preferencje w kwestii wyboru nazwy, wydaje się, że oba terminy odnoszą się do podobnego zakresu zjawisk. Część prac wręcz pomija kwestie definicyjne, być może zakładając, że znaczenie pojęcia zostało już de facto ukształtowane przez praktykę polityczną i można je uznać za oczywiste. Trafna w opisie interesującego mnie nurtu wypowiedzi jest definicja Lecha Nijakowskiego, zgodnie z która polityka pamięci oznacza „,wszelkie intencjonalne działania polityków i urzędników, które mają na celu utrwalenie, usunięcie lub redefinicję określonych treści pamięci społecznej. Działania te moga mieć charakter zarówno innowacji, jak i zrutynizowanych praktyk. Polityka pamięci zatem to nie wszelkie procesy społecznego zapamiętywania i zapominania, ale jedynie intencjonalne działania, które oczywiście moga podlegać strukturalnemu warunkowaniu i mieć także niezamierzone skutki (tak się najczęściej dzieje). Publiczny dyskurs historyczny mogą uprawiać przedstawiciele różnych profesji, ale do prowadzenia polityki pamięci wymagana jest publiczna legitymizacja"3. Uznaję powyższą definicję za reprezentatywną i wystarczającą na użytek dalszych analiz, jako że zawiera ona wszystkie podstawowe właściwości sposobu pojmowania polityki historycznej dominującego od kilku lat w polskiej

${ }^{3}$ L. M. Nijakowski, Baron Münchhausen, czyli o polskiej polityce pamięci, „Przegląd Polityczny” 2006, nr 75, s. 54-56; por. idem, Polska polityka pamięci..., s. 43-45. 
debacie publicznej. Podobne, nieco węższe i leksykalnie zróżnicowane próby definicji tego kluczowego pojęcia można znaleźć w pracach innych autorów ${ }^{4}$.

Same argumenty zwolenników nowej polityki historycznej nie sa przedmiotem mojego zainteresowania w niniejszym artykule, przedstawię je zatem jedynie w dużym skrócie.

U źródeł toczącej się debaty leży aktywność polityczna i publicystyczna środowisk związanych $\mathrm{z}$ konserwatywna prawica, która wprowadziła w obręb debaty publicznej postulat sformułowania nowej polityki historycznej. Uzasadnienie owego postulatu koncentrowało się wokół trzech fundamentalnych argumentów. Po pierwsze, globalne przemiany cywilizacyjne i kulturowe (między innymi globalizacja, fundamentalizm religijny i terroryzm), projekt konstruowania europejskiej wspólnoty ponadnarodowej oraz kryzys liberalnego projektu transformacji postkomunistycznej - na który wskazuja również autorzy programu nowej polityki historycznej ${ }^{5}$ - rodzą konieczność integracji wokół wartości patriotycznych, wzmocnienia poczucia tożsamości narodowej i wspólnego dziedzictwa Polaków, tak by mogli oni, jako wspólnota narodowa, uzyskać podmiotowość w przestrzeni międzynarodowej. Rafał Stobiecki stwierdza: „W opinii zwolenników tego pojęcia, prowadzenie polityki historycznej jest nie tylko obowiązkiem państwa i jego organów, ale wynika z naturalnego stanu rzeczy. Sądzą oni, że niemożliwe jest odseparowanie kolektywnej pamięci społeczeństwa od polityki, albowiem jest ona trwałym fundamentem każdej

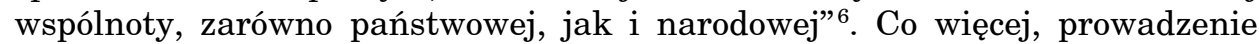
spójnej polityki historycznej jest warunkiem skuteczności działań symbolicznych na arenie międzynarodowej $\mathrm{w}$ sytuacji, gdy taka spójną politykę dyktowaną własnymi interesami prowadzą sassiedzi - Niemcy i Rosja wysuwając wobec Polski roszczenia polityczno-historyczne. W opinii zwolenników nowej polityki historycznej, elity III RP dopuściły się szeregu zaniedbań w dziedzinie konstruowania zbiorowej pamięci i tożsamości lub wręcz nie prowadziły żadnej polityki w tym obszarze, w ogóle usuwając kategorię szeroko pojętego interesu narodowego poza nawias obowiązującej poprawności politycznej. Dlatego politykę historyczną prowadzoną w ciągu piętnastu lat po 1989 r. Tomasz Merta nazywa ,,antypolityką" . Nowa polityka pamięci w swoim edukacyjnym aspekcie ma sprzyjać ukształtowaniu się pewnego modelu

${ }^{4}$ Por. np. D. Gawin, O pożytkach $i$ szkodliwości historycznego rewizjonizmu, w: R. Kostro, T. Merta (red.), Pamięć $i$ odpowiedzialność, Ośrodek Myśli Politycznej, Centrum Konserwatywne, Kraków-Wrocław 2005; R. Traba, Walka o kulturę. Przestrzeń dialogu w najnowszej debacie o polskiej historii i pamięci, „Przegląd Polityczny” 2006, nr 75; A. Wolff-Powęska, Polskie spory o historię i pamięć. Polityka historyczna, „Przegląd Zachodni” 2007, nr 1; R. Stobiecki, Historycy wobec polityki historycznej, w: S. M. Nowinowski, J. Pomorski, R. Stobiecki (red.), Pamięć i polityka historyczna. Doświadczenia Polski $i$ jej sqsiadów, Instytut Pamięci Narodowej, Łódź 2008; szczególnie interesujące, dlatego że uwzględnia różne nastawienia wartościujące, wyliczenie znaczeń terminu w: K. Zamorski, Nostalgia i wzniostość a refleksja krytyczna o dziejach. Kiedy ,,polityka historyczna” ma sens?, w: S. M. Nowinowski et al. (red.), op. cit.

${ }^{5}$ R. Kostro, K. M. Ujazdowski, Odzyskać pamięć, w: R. Kostro, T. Merta (red.), op. cit., s. 44-46.

${ }^{6}$ R. Stobiecki, op. cit., s. 177.

7 T. Merta, Pamięć i nadzieja, w: R. Kostro, T. Merta (red.), op. cit., s. 77; por. D. Gawin, op. cit., s. 2-3; A. Dudek, Spory o polska polityke historyczna po 1989 roku, w: S. M. Nowinowski et al. (red.), op. cit.; R. Kostro, K. M. Ujazdowski, op. cit.; W. Roszkowski, O potrzebie polskiej polityki historycznej, w: R. Kostro, T. Merta (red.), op. cit.; M. Cichocki, Czas silnych tożsamości, w: Polityka historyczna. Historycy - politycy - prasa. Konferencja pod honorowym patronatem Jana Nowaka-Jeziorańskiego, Muzeum Powstania Warszawskiego, Warszawa 2005. 
patriotyzmu, który będzie miał charakter afirmatywny: eksponował będzie te elementy polskiego doświadczenia historycznego, które są jednocześnie pozytywne, unikalne i wnosza wkład w dziedzictwo kulturowe Europy ${ }^{8}$. Tym samym zmarginalizuje długą tradycję „,patriotyzmu krytycznego”, dominująca po $1989 \mathrm{r}$.

W obrębie krytyki programu nowej polityki historycznej da się wyodrębnić dwa ogólne nurty. Pierwszy, który można nazwać „umiarkowanym”, opiera się na negacji tezy środowisk konserwatywnych, jakoby elity III RP były bierne w dziedzinie polityki historycznej. Jak sugeruja między innymi L. M. Nijakowski ${ }^{9}$ i Marek Czyżewski ${ }^{10}$, mieliśmy raczej do czynienia z ewolucyjnym przeobrażeniem polityki pamięci i dyskursu historiograficznego, zapoczątkowanym jeszcze $\mathrm{w}$ latach osiemdziesiątych ubiegłego stulecia. $\mathrm{W}$ umiarkowanym nurcie krytyki dominuje opinia, że przełom lat osiemdziesiątych i dziewięćdziesiątych dostarcza licznych przykładów praktyk z dziedziny polityki historycznej, zmierzajacych między innymi do zmiany symboliki państwowej, odwołań historycznych w przestrzeni publicznej czy też, na poziomie historiografii, do podjęcia badań problematyki wyeliminowanej w okresie PRL z pola badawczego historii ${ }^{11}$. Jednocześnie koncepcji ,afirmatywnego patriotyzmu" - w opinii krytyków opartej na wywodzącym się $\mathrm{z}$ tradycji XIX-wiecznego nacjonalizmu etnicznym interpretowaniu przynależności narodowej, eliminującej doświadczenie mniejszości kulturowych i sprzyjającej megalomanii - przeciwstawia się ,,patriotyzm krytyczny”, obywatelski, nieantagonistyczny ${ }^{12}$. Drugi nurt krytyki - można nazwać go „,radykalnym" - ze względu na swą wagę teoretyczną zasługuje na omówienie w osobnej części artykułu.

\section{PRAKTYKA POLITYKI HISTORYCZNEJ A NAUKA}

By kontekst argumentacji radykalnych krytyków polityki historycznej był bardziej zrozumiały, niezbędnych jest kilka uwag na temat relacji między kategoriami „pamięć zbiorowa” a „historia”. W ujęciu Barbary Szackiej pamięć zbiorowa jest całością „,wyobrażeń członków zbiorowości o jej przeszłości, o zaludniających ja postaciach i minionych wydarzeniach, jakie w niej zaszły, a także sposobów ich upamiętniania i przekazywania o nich wiedzy uważanej za obowiązkowe wyposażenie członka tej zbiorowości. Inaczej mówiąc, jako wszystkich świadomych odniesień do przeszłości, które występują w bieżącym życiu zbiorowym" ${ }^{13}$. Tak rozumiana pamięć pełni dwie istotne funkcje: legitymizacji władzy i podtrzymywania tożsamości zbiorowej ${ }^{14}$.

\footnotetext{
${ }^{8}$ R. Kostro, K. M. Ujazdowski, op. cit., s. 50-52.

${ }^{9}$ L. M. Nijakowski, Baron..., s. 54.

${ }^{10}$ M. Czyżewski, Debata na temat Jedwabnego oraz spór o ,politykę historyczna” z punktu widzenia analizy dyskursu publicznego, w: S. M. Nowinowski et al. (red.), op. cit., s. 123-125 i 135-136.

11 Por. A. Wolff-Powęska, op. cit., s. 22-24; M. Czyżewski, op. cit., s. 123-124.

12 Por. M. Janowski, Polityka historyczna: między edukacja historyczna a propaganda, w: S. M. Nowinowski et al. (red.), op. cit., s. 229-235; R. Stobiecki, op. cit., s. 182-185; A. Wolff-Powęska, op. cit., s. 26-29; D. Gawin, op. cit.

${ }_{13}$ B. Szacka, Czas przeszty, pamięć, mit, Scholar, Warszawa 2006, s. 19.

14 Ibidem, s. 47-58; por. B. Szacka, Pamięć zbiorowa i wojna, „Przegląd Socjologiczny” 2000, nr 2.
} 
Historia zaś, choć ze względu na podobieństwo konstruowanego przedmiotu wiedzy można ją uznać za specyficzną formę zbiorowej pamięci przeszłości, dysponuje historycznie ukształtowaną autonomią, na która składają się trzy elementy: 1) instytucjonalizacja i profesjonalizacja $\mathrm{w}$ obrębie niezależnych placówek badawczych; 2) istnienie norm postępowania badawczego i krytycznej analizy źródeł, które obowiązują każdego, kto aspiruje do roli historyka i których przestrzeganie stanowi kryterium naukowości wypowiedzi profesjonalnego historyka; 3) dążenie do realizacji wzoru obiektywnej nauki jako podstawa etosu profesjonalnego. Nie przesądza się tu, w jakim stopniu dążenie do obiektywności jest możliwe do zrealizowania, trzeba natomiast podkreślić, że , w odbiorze społecznym historia jest postrzegana jako zmierzająca $\mathrm{w}$ tym kierunku i takie są wobec niej oczekiwania" ${ }^{15}$. W literaturze przedmiotu często przyjmuje się następujące rozróżnienie: o ile stosunek do przeszłości wyrażający się w pamięci zbiorowej można określić jako ,,praktyczny” i służący doraźnym potrzebom, o tyle stosunek historyczny do przeszłości zakłada, że sama przeszłość stanowi przedmiot zainteresowań.

Gdy weźmie się w nawias problematyczność wspomnianej opozycji, ta krótka charakterystyka obu typów wiedzy o przeszłości pozwala zrozumieć, dlaczego liczni badacze bronią rozgraniczeń pomiędzy naukową historią a pozaprofesjonalnymi formami wiedzy, ustanowionych w długim procesie specjalizacji dyscypliny naukowej. Historycy odnosząc się do pamięci, moga ja traktować jako świadectwo (krytycznie analizowana pamięć zbiorowa jest jednym $\mathrm{z}$ uprawomocnionych źródeł naukowej wiedzy historycznej), ich produkcja intelektualna współkształtuje przekonania dotyczące przeszłości rozpowszechnione w społeczeństwie, jednak historii nie można zredukować do pamięci. Tymczasem ,,polityka historyczna w znaczeniu przyjmowanym dzisiaj jest rodzajem polityki. Jak każda polityka, jest w istocie bardziej zainteresowana teraźniejszością i przyszłością aniżeli przeszłością. Chce widzieć historię jako pamięć, choć nie dostrzega przy tym, że pamięć pojawiła się w koncepcjach postmodernistycznych jako przeciw-historia" ${ }^{16}$. Ze względu na wymienione powyżej przesłanki autonomii naukowej historia ma pozostać uprzywilejowana forma wiedzy. Uruchomienie szeregu strategii dyskursywnych mających na celu ponowne zaakcentowanie odrębności naukowej historii jest zatem reakcja na rozpoznane zagrożenie ze strony coraz powszechniejszego $\mathrm{w}$ świadomości potocznej utożsamiania pamięci $z$ historia. A. Wolff-Powęska wyraża wręcz obawę, że uprzywilejowanie pamięci oraz polityka historyczna odwracają uwagę opinii publicznej od faktów ustalanych przez historyków w toku ich pracy badawczej, kierując ją jednocześnie na kontekst wiedzy o przeszłości (,jak, kiedy, dlaczego i przez kogo przywoływana jest pamięć" ${ }^{17}$.

Radykalnym krytykom w środowisku historyków polityka historyczna jawi się jako narzędzie przymusu wobec przedstawicieli nauki oraz narzędzie politycznej manipulacji wypowiedziami naukowymi. Narzuca ona bowiem pewną konwencję uprawiania historii, zdaniem wielu: niedającą się pogodzić ze

15 B. Szacka, Czas..., s. 25.

${ }^{16}$ K. Zamorski, op. cit., s. 57.

17 A. Wolff-Powęska, op. cit., s. 15. 
standardami profesjonalnego krytycyzmu, w której priorytetowym celem historii (a przynajmniej jej najbardziej doniosła społecznie funkcją) jest budowanie tożsamości wspólnoty narodowej ${ }^{18}$. Andrzej Werner posunął się do stwierdzenia, że zajmowanie się polityką historyczna jest dla historyka równoznaczne ze swoistym samobójstwem zawodowym, gdyż w ten sposób aktywnie uczestniczy on $\mathrm{w}$ instrumentalizacji historii, przerywając proces badania przeszłości na rzecz uprawomocnienia określonego stanu wiedzy - tego, który jest zgodny z interesami podmiotu realizującego dominującą politykę pamięci ${ }^{19}$.

Kierowanie się $\mathrm{w}$ badaniach i pisarstwie historycznym jakimkolwiek interesem zewnętrznym wobec wąsko pojmowanego interesu poznawczego narusza normy etosu zawodowego i metodologii historii, a co za tym idzie - grozi zakwestionowaniem naukowego statusu tej dyscypliny. Tymczasem interes stojący za zainteresowaniem historia $\mathrm{w}$ perspektywie polityki historycznej jest z założenia (i zupełnie otwarcie) pozanaukowy i wynika z indywidualnego bądź grupowego zaangażowania w bieżący konflikt polityczny. Wykorzystanie historii w debacie publicznej jest wskutek tego poznawczo płytkie ${ }^{20}$. Co ciekawe być może jest to rezultatem polemicznego charakteru omawianych tu wypowiedzi i w innych okolicznościach linia argumentacji byłaby nieco innaautorzy sięgający po ten argument zazwyczaj konceptualizują naukowy status historii w kategoriach właściwych pozytywistycznej ideologii nauki. Konstruuje się zatem dwa biegunowe typy idealne: z jednej strony politykę, której praktyka cechuje się doraźnością, emocjonalnością i ma nieusuwalnie konfliktowy charakter, z drugiej - historię, która rządzi się regułami racjonalności, dystansu wobec przedmiotu i długiego trwania ${ }^{21}$. W ten sposób historycy krytycznie nastawieni do polityki historycznej przywołuja mocno zakorzeniony $\mathrm{w}$ teorii historiografii model badacza: „,neutralnego obserwatora, zimnego scjentysty, bezstronnego poszukiwacza prawdy" ${ }^{22}$, który w swej pracy naukowej pozostaje poza wpływem czynników kontekstualnych, zajmując pozycję w pełni neutralną i zewnętrzną wobec badanej rzeczywistości historycznej, pojmowanej jako obiektywny stan rzeczy, dający się adekwatnie opisać dzięki zastosowaniu odpowiednich reguł metodologicznych ${ }^{23}$. W takim rozumieniu rzetelnie uprawiana historia, wbrew temu, co chca osiagnąc zwolennicy nowej polityki historycznej, nie pozwala się więc zakwalifikować jako afirmatywna względem jakiejkolwiek idei politycznej, ponieważ przedstawia samą siebie jako krytyczną wedle własnych, wewnątrznaukowych kryteriów.

„Historia nie jest moralnością. Nie jest rolą historyka wychwalanie lub skazywanie, on wyjaśnia [...]. Historia nie jest przedmiotem prawa. W wolnym państwie określenie prawdy historycznej nie jest sprawą ani parlamentu, ani

${ }^{18}$ K. Zamorski, op. cit., s. 56; por. R. Stobiecki, op. cit., s. 178-179.

${ }^{19}$ A. Werner, Pamięć i władza: komu stuży polityka historyczna, „Przegląd Polityczny” 2006, nr 76.

${ }^{20}$ Por. M. Kula, Lepiej nie nadużywać (historii), „Przegląd Polityczny” 2006, nr 76, s. 45.

${ }^{21}$ Por. A. Wolff-Powęska, op. cit., s. 11.

${ }^{22}$ R. Stobiecki, Historyk $i$ jego rola we wspótczesnym świecie, w: G. Dominiak, J. Ostoja-Zagórski, W. Wrzosek (red.), Gra i konieczność. Zbiór rozpraw z filozofii historii i historii historiografii, Epigram, Bydgoszcz 2005, s. 50.

${ }^{23}$ Ibidem, s. 55 . 
autorytetów prawniczych" ${ }^{24}$. Powyższy cytat, w którym autor referuje tezy listu historyków francuskich protestujących przeciw ustawom ingerującym w ustalenia badawcze ich nauki (petycja $O$ wolność dla historii z 13 grudnia 2005 r.), w zwięzłej formie streszcza sens czwartego z głównych argumentów pojawiających się w radykalnej krytyce polityki historycznej. Znaczna część głosów poparcia dla nowej polityki historycznej operuje metaforyka przedstawiająca historię w roli sędziego zdolnego rozstrzygać dawne spory między państwami i innymi podmiotami polityki oraz dokonywać moralnej oceny działań. Sądy te maja ponadto mieć walor edukacyjny, a więc służyć upowszechnieniu pożądanych wzorów postaw wśród odbiorców narracji historycznych. Ten sposób myślenia jest szczególnie widoczny tam, gdzie polityka historyczna rozpatrywana jest jako instrument prowadzenia sporów w polityce międzynarodowej ${ }^{25}$. Taka interpretacja oczekiwań społecznych wobec historyka budzi sprzeciw części środowiska naukowego z przynajmniej trzech zasadniczych powodów.

Po pierwsze, metafora sędziego sugeruje, że naukowiec jest w stanie wydać wyrok ostateczny, a więc implikuje petryfikację wiedzy historycznej, tymczasem rzetelnie uprawiana historia winna zakładać możliwość wielokrotnej weryfikacji ustaleń. Po drugie, metafora ta może wskazywać, że rezultatem badania jest wydanie werdyktu, który odpowiedzialność (sprawstwo, winę) przypisuje wyłącznie jednemu z protagonistów zdarzeń (jednostce, grupie, organizacji, kategorii etnicznej i tak dalej), tymczasem krytyczność historii ma wyrażać się między innymi w uwzględnianiu złożoności kontekstu, wielości czynników sprawczych, różnorodności perspektyw uczestnictwa i oceny wydarzeń. Po trzecie wreszcie, kontrowersyjne wydaje się założenie, że wydawane przez historyków orzeczenia i sądy moralne mają walor dydaktyczny, gdyż historia ma uświadamiać różnorodność i złożoność możliwych ocen, umożliwiać zdystansowane spojrzenie, ostateczną decyzję pozostawiając odbiorcy ${ }^{26}$.

\section{ZAŁOŻENIA POLITYKI HISTORYCZNEJ JAKO DYSKURSU}

Podsumowaniem tej części rozważań niech będzie kilka ogólnych uwag o dyskursie polityki historycznej. Oczywiście nie będzie to analiza dyskursu w pełnym znaczeniu tego pojęcia, chociażby w postaci zaproponowanej przez Michela Foucaulta ${ }^{27}$. Niemniej warto poczynić kilka obserwacji na temat polityki historycznej jako dyskursu (w szerokim rozumieniu: jako dającego się wyodrębnić systemu wypowiedzi, czyli artykulacji wiedzy z pewnego obszaru). Uwagi te dotyczyć będą kontekstu instytucjonalnego dyskusji o polityce historycznej oraz założeń wspólnych, częściowo nieartykułowanych, składających się na pierwotny umożliwiający debatę konsensus.

${ }^{24}$ K. Zamorski, op. cit., s. 57.

${ }^{25}$ Zob. np. A. Dudek, op. cit., s. 199-200; D. Gawin, op. cit., s. 25-28; Z. Krasnodębski, Zwycięzcy i pokonani, w: R. Kostro, T. Merta (red.), op. cit.

${ }^{26}$ Szersze omówienie tej linii argumentacji m.in. w: M. Janowski, op. cit., s. 236-245; R. Stobiecki, Historycy..., s. 188-190; K. Zamorski, op. cit., s. 57.

${ }^{27}$ M. Foucault, Archeologia wiedzy, Państwowy Instytut Wydawniczy, Warszawa 1977; por. J. Topolski, Wstep, w: ibidem, s. 10-12. 
Specyficzną cechą omawianej debaty jest nieco paradoksalny fakt, że choć została ona zainicjowana i zdefiniowana przez podmioty aktywne $\mathrm{w}$ sferze polityki instytucjonalnej, większość jej uczestników to profesjonalni historycy. Sporadycznie pojawiają się przedstawiciele innych dziedzin humanistyki (socjologia, politologia, antropologia kulturowa, filozofia, historia idei), czynni politycy stanowią wyjątek. W efekcie w wielu wypadkach mamy do czynienia ze sporem pomiędzy historykami, który jednak nie dotyczy samej historii, gdyż w toku prezentacji stanowisk nie odwołują się oni do ustaleń badawczych, a więc do samego przedmiotu pracy naukowej historyka, ale raczej dotyczy warunków, w których praktyka naukowa się odbywa. Wypowiedzi składające się na dyskurs polityki historycznej odnoszą się zatem w równym stopniu do sensu polityki historycznej (użycia wiedzy o przeszłości w celach legitymizacji i konstrukcji tożsamości), jak i do charakteru relacji między naukową historią a polityką.

Zarówno zwolennicy, jak i przeciwnicy projektu polityki historycznej zgodni są co do tego, że jest ona zbiorem intencjonalnych działań, skoordynowanych określonym programem. Podmiotami realizującymi tego rodzaju politykę są w pierwszej kolejności instytucje państwa, dlatego też zazwyczaj pojmuje się ja jako centralnie projektowaną i realizowaną przede wszystkim poprzez wielkie uroczystości i przedsięwzięcia o zasięgu ogólnonarodowym. Zakres, sens i uprawomocnienie tych działań sa tematem większości branych tu pod uwagę wypowiedzi. Powyższe obserwacje dotyczą jednak wyłącznie warunków, na które otwarcie wyrażaja zgodę uczestnicy debaty. Znacznie bardziej interesująca wydaje się odpowiedź na pytanie o założenia, które w ogromnej większości przypadków pozostają niewyartykułowane.

Po pierwsze, zakłada się milcząco, że tożsamość zbiorowości, w obrębie której realizuje się jakaś politykę historyczną, jest homogeniczna i w swoich ogólnych ramach nieproblematyczna. Innymi słowy: mieszkańcy Polski $\mathrm{z}$ założenia traktuja przynależność narodowa jako istotną płaszczyznę zbiorowej identyfikacji. W związku z tym przyjmuje się również, że w ponowoczesnym świecie patriotyzm może być istotną i trwałą dyspozycją nie tylko na poziomie deklaratywnym, a więc jego dominująca forma jest ważnym zagadnieniem publicznym.

Po drugie, dyskurs polityki historycznej ma ściśle elitarny charakter: przedmiotem zainteresowania jest to, w jaki sposób elity polityczne i intelektualne moga być odpowiedzialne za budowanie zbiorowej tożsamości w określonym kształcie. Natomiast jedynie w wyjątkowych przypadkach pojawia się refleksja nad tym, w jaki sposób pamięć zbiorowa i tożsamość splatają się na poziomie grup pierwotnych, społeczności lokalnych i regionalnych, mniejszości kulturowych czy grup religijnych, w jaki sposób poza kręgiem elit centralnych podejmowane sa mniej lub bardziej świadome próby sformułowania partykularnej polityki historycznej.

Po trzecie, z punktu widzenia polityki historycznej centralną kategoria jest naród rozumiany przede wszystkim jako wspólnota etniczna lub kulturowa, znacznie rzadziej - jako wspólnota obywatelska. Wiąże się to z dominacja szczególnie w wypowiedziach zwolenników tak zwanej nowej polityki historycznej - kategorii pojęciowych właściwych klasycznej historiografii 
narodu i odwołań do narracji historycznych tworzonych zgodnie $\mathrm{z}$ tym paradygmatem. Milcząco uznaje się historiografię klasyczną za historię w ogóle. Polityka historyczna bazuje zatem na nurcie pisarstwa historycznego ukształtowanym w XIX w., dominującym w ubiegłym stuleciu, a obecnie, zdaniem niektórych badaczy, nieodwracalnie tracącym na znaczeniu. Tradycyjna synteza historii narodowej jest historiografią wydarzeniowa, w centrum narracji stawiająca antropomorfizowany naród i jego udramatyzowane dzieje polityczne, począwszy od mitologizowanej genezy. Co więcej, schematy pojęciowe, metafory historiograficzne i sposoby antropomorfizacji ukształtowane przez tę konwencję pisarstwa historycznego organizują potoczną wiedzę o przeszłości ${ }^{28}$.

\section{ALTERNATYWNE UJECIE: MICHELA FOUCAULTA WIZJA HISTORII}

Jak starałem się wykazać w poprzedniej części mojego wywodu, dyskurs polityki historycznej znany nam z obserwacji debaty publicznej w Polsce operuje specyficznym rozumieniem zarówno historii, jak i polityki, traktując te kategorie jako same przez się zrozumiałe i jedynie w wyjątkowych sytuacjach wykazując zainteresowanie partykularnością przyjętej perspektywy. Sądzę, że istnieje przynajmniej jeden inny sposób konceptualizacji relacji zachodzących między historią a polityką. Alternatywę, o której tu piszę, można zrekonstruować na podstawie myśli Michela Foucaulta, mieszczącej w sobie między innymi nieklasyczny projekt historiografii. Jakie są podstawowe składniki tego projektu?

Kluczowe znaczenie w obrębie foucaultowskiego projektu ma uprawianie historii w formie genealogii. Genealogia opisywana jest przez M. Foucaulta jako praktyka badawcza zrywająca z tradycyjnym modelem historii, który dzieje (instytucji, wartości, pojęcia itd.) rozpatruje w kategoriach ciągłości, poszukuje ,źródła” - rozumianego jako istota rzeczy - a więc układa zdarzenia w pewnym teleologicznym porządku, podporządkowanym jakiejś ponadhistorycznej idei. Genealogia ma natomiast ukazywać zerwania, zwroty, wyłanianie się obecnego ładu, wiedzy i poczucia tożsamości $\mathrm{z}$ wielości skonfliktowanych ze soba tendencji. Obiektem jej zainteresowania nie jest metafizyczne „źródło”, ale „pochodzenie” i ,wyłanianie”. „Pochodzenie pozwala również odkryć pod szczególnym aspektem cechy bądź pojęcia mnożenie się zdarzeń, poprzez które (dzięki którym, przeciw którym) powstały. Genealogia nie pragnie rekonstruować czasu, aby ustanowić wielką ciagłość ponad rozproszeniem zapomnienia [...]. Nic, co miałoby przypominać ewolucję gatunku czy przeznaczenie narodu. Przeciwnie, śledzić złożony ciąg pochodzenia, to utrzymywać przeszłość we właściwym jej rozproszeniu: wskazywać na wypadki, nieznaczne odchylenia - albo, przeciwnie, całkowite odwrócenia - błędy, mylne oceny, chybione

${ }^{28}$ T. Stryjek, Przeszłość narodu i nurty dwudziestowiecznej historiografii, „Kultura i Społeczeństwo" 2001, nr 3-4, s. 123-124; M. Janowski, op. cit., s. 235; por. W. Wrzosek, Historia - kultura metafora. Powstanie nieklasycznej historiografii, Fundacja na Rzecz Nauki Polskiej, Wrocław 1995. 
kalkulacje, które zrodziły to, co istnieje i co ma dla nas wartość; to odkryć, że u podstaw tego, co poznajemy, i tego, czym jesteśmy, nie tkwi bynajmniej prawda i byt, lecz zewnętrzność przypadku" ${ }^{29}$. W ten sposób historia pisana zgodnie z zaleceniami M. Foucaulta odsłania historyczność i przypadkowość ładu społecznego i poznawczego, któremu tradycyjny dyskurs historii przypisywał uniwersalne uzasadnienie. Już na podstawie tych uwag można stwierdzić, że sprzężenie historii i polityki jest w omawianej koncepcji oczywiste.

Historia jest dyskursem władzy, środkiem umożliwiającym uprawomocnienie istniejącego ładu oraz wielorakich form władzy funkcjonujacych $\mathrm{w}$ stosunkach społecznych ${ }^{30}$. Historia naukowa, uprawiana w klasycznej konwencji, ze zrozumiałych względów dostarcza uprawomocnienia szczególnie tym relacjom władzy, które składają się na aparat państwa i podtrzymuja jednolita tożsamość populacji mu podlegającej. Trzeba pamiętać, że w teorii M. Foucaulta władza nie polega na „ogólnej i jednorodnej dominacji” jednej jednostki, grupy czy klasy nad pozostałymi, ale stanowi raczej sieć stosunków dominacji i oporu, stwarzająca wiele możliwych płaszczyzn binarnego podziału społeczeństwa ${ }^{31}$.

Jednak nie każda forma uprawiania historii stanowi legitymizację władzy. M. Foucault powiada, że około XVI-XVII w. pojawiła się nowa perspektywa historiograficzna, zwana przez niego dyskursem historyczno-politycznym. Jego najistotniejszą tendencja było opisywanie stosunków społecznych za pomoca metafory wojny, traktowanej jako stałe podłoże stosunków i instytucji władzy. Jako że przestrzeń historyczna jest przestrzenią nieustającego konfliktu, pisanie historii odbywa się zawsze z perspektywy którejś ze stron - zwycięzców lub pokonanych. Nowy dyskurs pojawia się jako głos przegranych, świadomych partykularności swojej perspektywy poznawczej. Jest jednocześnie krytyka zastanego porządku, żądaniem rewindykacji. Zatem „krytyka” w tej koncepcji oznacza praktykę emancypacyjną - nie jest tym samym, co „krytyczność” historii pojmowanej jako obiektywna, zdystansowana nauka, w sensie zarysowanym wcześniej. Dyskurs jest określany jako historyczno-polityczny dlatego, że ,podmiot, który w tym dyskursie przemawia, który mówi »ja albo »my«, nie może, i zresztą wcale się o to nie stara, zajmować pozycji prawnika albo filozofa, to znaczy pozycji uniwersalnego, totalizującego lub neutralnego podmiotu. W ogólnej walce, o której mowa, ten, kto mówi, kto mówi prawdę, kto opowiada historię, kto odświeża pamięć i pokonuje zapomnienie, ten ktoś należy nieuchronnie do jednego albo do drugiego obozu: prowadzi bitwę, ma przeciwników, pracuje na rzecz partykularnego zwycięstwa" ${ }^{32}$.

${ }^{29}$ M. Foucault, Nietzsche, genealogia, historia, w: idem, Filozofia, historia, polityka. Wybór pism, WN PWN, Warszawa-Wrocław 2000, s. 118-119; por. M. Solarska, Historia zrewoltowana. Pisarstwo historyczne Michela Foucaulta jako diagnoza teraźniejszości i projekt przyszłości, Instytut Historii UAM, Poznań 2006, s. 35-45.

${ }^{30}$ Por. M. Solarska, „Walczymy wszyscy przeciw wszystkim” - historia spod znaku niezgody, w: H. Mamzer (red.), Formy przemocy w kulturze wspótczesnej, Wydawnictwo Naukowe UAM, Poznań 2006 , s. 45.

${ }^{31}$ M. Foucault, Trzeba bronić spoteczeństwa, KR, Warszawa 1998, s. 39.

32 Ibidem, s. 60; por. M. Solarska, ,Walczymy...”, s. 48. 
Przedstawienie historii jako narracji pisanej z perspektywy uczestnika konfliktu społecznego nie jest oczywiście charakterystyczne wyłącznie dla M. Foucaulta. Konfliktowy charakter przedstawień przeszłości dostrzega również Krzysztof Pomian ${ }^{33}$, choć formułuje on odmienne wnioski co do możliwości uprawiania historii jako zdystansowanej i obiektywnej nauki. K. Pomian zauważa, że pojawienie się $\mathrm{w}$ przestrzeni historycznej konfliktu społecznego w sposób nieunikniony generuje dwie przeciwstawne pamięci: pamięć zwycięzców i pamięć zwyciężonych, które stanowią przedłużenie dawnego konfliktu w płaszczyźnie świadomościowej (nie każda wypowiedź o przeszłości ma tu status pamięci -jedynie ta, która wyrasta z utożsamiania się z któraśs ze stron uwikłanych w minione wydarzenia, czyli ma konsekwencje tożsamościowe). Pomiędzy pamięcią zwyciężonych a pamięcią zwycięzców istnieje jednak nieusuwalna dysproporcja możliwości artykulacji i transmisji, gdyż jedynie zwycięzcy mają dostęp do wszelkich środków przekazu i aparatu edukacji; innymi słowy: jedynie pamięć zwycięzców może stanowić jawny, publiczny dyskurs. Pamięć pokonanych ma status prywatny, w pewnych okolicznościach wręcz ukryty ${ }^{34}$.

Pamięć zwycięzców może występować pod postacią historii, gdy wyposaży się ja w pewne rozpoznawalne atrybuty naukowości. Nie przestaje przy tym być rezultatem utożsamienia się z jedną ze stron przeszłego konfliktu. Staje się wówczas historią urzędową (państwową), a w opozycji do niej pamięć zwyciężonych może przybrać postać historii rewizjonistycznej. Spór historii jest symbolicznym przedłużeniem konfliktu pamięci, rozgrywającym się na polu nauki instytucjonalnej, jednak nie pozbawionym emocji, poczucia krzywdy i przekonania o słuszności. Historia staje się tym samym formą przemocy symbolicznej. Zarówno urzędowa, jak i rewizjonistyczna, pozostaja ,,pamięciami wyposażonymi w oznaki historyczności”, stanowią „historię, która nie jest krytyczna i która przeto sama musi być poddana krytyce, by obnażyć podstawę tożsamościową, jaką jest przesycona, i ustalić, co można z niej zachować, gdy przyjmuje się perspektywę zasadniczo różną od tej, jaka jest jej właściwa: zewnętrzną w stosunku do konfliktu, który dał jej początek" ${ }^{35}$.

K. Pomian konstruuje pewien typ idealny historii krytycznej. Jej wyznacznikiem jest dystans badacza, wyrażający się w tym, że jego stosunek do przeszłości nie jest regulowany nastawieniami tożsamościowymi, a jedynie zasadami metodologii historii jako nauki. „Jak utożsamianie się z przeszłością jest konstytutywne dla pamięci, tak dystansowanie się wobec niej jest konstytutywne dla historii. Przejście od nastawienia pamięciowego do nastawienia historycznego, od pamięci do historii, polega właśnie na przecięciu utożsamiania się $\mathrm{z}$ przeszłością. W przypadku idealnym historyk staje się historykiem, gdy nie utożsamia się z żadną ze stron konfliktu, którego historię

${ }^{33}$ K. Pomian, Historia urzędowa, historia rewizjonistyczna, historia krytyczna, „Przegląd Polityczny” 2006, nr 77. Cytowany tekst znajduje się również w: K. Pomian, Historia - nauka wobec pamięci, Wydawnictwo UMCS, Lublin 2006.

${ }^{34}$ K. Pomian, Historia urzędowa..., s. 78-79.

${ }^{35}$ Ibidem, s. 80-81. 
bada czy, ogólniej, z żadnym protagonistą zdarzeń, o których pisze" ${ }^{36}$. Historia krytyczna ma zatem sytuować się na zewnątrz konfliktu źródłowego i związanych z nim nastawień tożsamościowych (bez których pozostałe dwa typy historii straciłyby sens i uległy rozkładowi), zgadzać się z historiami uwikłanymi w konflikt jedynie w partykularnych kwestiach i opierać na własnych, zewnętrznych kryteriach. Problem historii krytycznej polega na tym, że „granica między zewnętrznością a utożsamianiem się, choć wyrazista w przypadkach skrajnych, nie daje się łatwo wytyczyć ani we własnej pracy, ani w cudzej” ${ }^{37}$. Skoro praktyka historii narusza to rozgraniczenie, to należy zastanowić się, czy rozróżnienie historii krytycznej od historii urzędowej/rewizjonistycznej nie ma charakteru przede wszystkim teoretycznego.

W koncepcji M. Foucaulta możliwość uzyskania krytycznego dystansu $\mathrm{w}$ powyższym rozumieniu jest $\mathrm{z}$ założenia fałszywa. Historia - według jego projektu - może zatem otwarcie służyć wyeksponowaniu głosu tych, którzy przez główny nurt historiografii są pomijani. Umożliwia również wprowadzanie do analiz historycznych kategorii analitycznych i zakresów problemowych wcześniej nieobecnych, takich jak rasa, gender czy choroba psychiczna. Wpisuje się w ten sposób w istotny trend ponowoczesności, polegający na poszukiwaniu przez grupy mniejszościowe i kategorie zmarginalizowane lub wykluczone z przestrzeni publicznej własnej tożsamości i historii w celu przeciwstawienia się dominującej narracji. Można to ująć $\mathrm{w}$ kategoriach zmiany hierarchii elementów składających się na poczucie tożsamości ${ }^{38}$. Jest to zarazem sprzeciw wobec dominacji wiedzy powstającej w kontekście nauki akademickiej. „W gruncie rzeczy chodzi o to, by wiedzę lokalna, nieciagła, zdyskwalifikowana, nieprawomocna rozegrać przeciwko jednolitej instancji teoretycznej, która ma pretensje do sublimowania, hierarchizowania, porządkowania tej wiedzy w imię prawdziwego poznania, w imię praw nauki, jakie ponoć posiedli niektórzy [...]. Chodzi o bunt wiedzy. Nie tyle przeciwko treściom, metodom lub pojęciom jakiejś nauki, ile w pierwszym rzędzie przeciwko efektom centralistycznej władzy, związanej z instytucją i funkcjonowaniem zorganizowanego dyskursu naukowego w społeczeństwie takim jak nasze" ${ }^{39}$. Gdy uwzględni się marginalne wersje przeszłości i uzna je za polityczne, pojęcie polityki historycznej nabiera nowego sensu. Nie da się wówczas opisywać jej za pomoca prostego schematu transmisji ujednoliconego korpusu wiedzy z centrum (państwo) na zewnątrz (obywatele). Kontekstów powstawania pamięci jest bowiem wiele.

mgr Michat Machnikowski

Uniwersytet Wroctawski

machnikowski.m@gmail.com

\footnotetext{
${ }^{36}$ Ibidem, s. 79.

37 Ibidem, s. 80-81.

${ }^{38}$ T. Stryjek, op. cit., s. 138-139.

${ }^{39}$ M. Foucault, Trzeba..., s. 21.
} 


\section{HISTORICAL POLITICS AND ITS LIMITATIONS}

\section{Summary}

The paper addresses the discourse of historical politics developed in Poland in the first decade of the 21st century, as well as its limitations caused by the opposition of many of professional historians and by some implicit assumptions, such as the assumption of the homogeneity of the subject of collective memory; the assumption of the elite character of the discourse; or the nation as a central category. An alternative account of relations between history, memory and politics can be found, among others, in the works of Michel Foucault. 
